\title{
Content of inorganic solutes in lettuce grown with brackish water in different hydroponic systems
}

\author{
Alide M. W. Cova ${ }^{1}$, Fabio T. O. de Freitas ${ }^{1}$, Paula C. Viana ${ }^{1}$, \\ Maria R. S. Rafael ${ }^{1}$, André D. de Azevedo Neto ${ }^{2} \&$ Tales M. Soares ${ }^{1}$ \\ ${ }^{1}$ Universidade Federal do Recôncavo da Bahia/Centro de Ciências Agrárias, Ambientais e Biológicas. Cruz das Almas, BA. E-mail: alidewatanabe@yahoo.com.br \\ (Corresponding author); oibaf.freitas@hotmail.com; paulinhatmgm@hotmail.com; mariaph1201@gmail.com; talesmiler@gmail.com \\ ${ }^{2}$ Universidade Federal do Recôncavo da Bahia/Centro de Ciências Exatas e Tecnológicas. Cruz das Almas, BA. E-mail: andre@ufrb.edu.br
}

Key words:

soilless cultivation

Lactuca sativa

salinity

NFT and DFT systems

\begin{abstract}
A B S T R A C T
The objective of this study was to evaluate the growth and accumulation of ions in lettuce grown in different hydroponic systems and recirculation frequencies. The experimental design was randomized blocks with 8 treatments and 4 replicates. The evaluated hydroponic systems were Nutrient Flow Technique (NFT) and an adapted Deep Flow Technique (DFT), the latter with recirculation frequencies of $0.25,2$ and $4 \mathrm{~h}$. Both systems used fresh water and brackish water. Plant growth, accumulation of inorganic solutes $\left(\mathrm{Na}^{+}, \mathrm{K}^{+}, \mathrm{Cl}^{-}\right.$and $\mathrm{NO}_{3}{ }^{-}$) and the correlation between dry matter production and $\mathrm{Na}^{+} / \mathrm{K}^{+}$and $\mathrm{Cl}^{-} / \mathrm{NO}_{3}^{-}$were evaluated. The salinity of the water used to prepare the nutrient solution caused decrease in growth and $\mathrm{K}^{+}$and $\mathrm{NO}_{3}^{-}$levels, and increased contents of $\mathrm{Na}^{+}$and $\mathrm{Cl}^{-}$in the plants. When using fresh water the highest dry matter production was obtained in the NFT system. In case of brackish water the adapted DFT system increased the production, in relation to NFT system (at same recirculation frequency: $0.25 \mathrm{~h}$ ). It was found that the choice of the type of hydroponic system and recirculation interval for the cultivation of lettuce depends on the quality of the water used to prepare the nutrient solution.
\end{abstract}

\section{Palavras-chave: cultivo sem solo Lactuca sativa salinidade} sistemas NFT e DFT

\section{Teor de solutos inorgânicos em alface cultivada com água salobra em diferentes sistemas hidropônicos}

\begin{abstract}
R E S U M O
Objetivou-se, neste trabalho, avaliar o crescimento e o acúmulo de íons em alface cultivada em diferentes sistemas hidropônicos e frequências de recirculação. O delineamento experimental foi o aleatorizado em blocos com 8 tratamentos e 4 repetições. Os sistemas hidropônicos avaliados foram a Técnica do Fluxo Laminar de Nutrientes (NFT) e a Técnica do Fluxo Profundo (DFT) adaptada, este último com frequências de recirculação de 0,25, 2 e $4 \mathrm{~h}$. Foi utilizada, em ambos os sistemas, água doce e água salobra. Foram avaliados o crescimento, o acúmulo de solutos inorgânicos $\left(\mathrm{Na}^{+}, \mathrm{K}^{+}, \mathrm{Cl}^{-}\right.$e $\left.\mathrm{NO}_{3}^{-}\right)$e a correlação entre a produção de matéria seca e a relação $\mathrm{Na}^{+} / \mathrm{K}^{+} \mathrm{e} \mathrm{Cl}^{-} / \mathrm{NO}_{3}$. A salinidade da água utilizada no preparo da solução nutritiva proporcionou diminuição no crescimento e nos teores de $\mathrm{K}^{+} \mathrm{e} \mathrm{NO}_{3}^{-}$e aumentou os teores de $\mathrm{Na}^{+}$e $\mathrm{Cl}^{-}$nas plantas. Quando foi empregada água doce, o sistema NFT proporcionou maior produção de massa de matéria seca. No caso de água salobra o sistema DFT adaptado aumentou a produção, em relação ao sistema NFT (na mesma frequência de recirculação: $0,25 \mathrm{~h}$ ). Verificou-se que a escolha do sistema hidropônico e do intervalo de recirculação para o cultivo da alface depende da qualidade da água utilizada no preparo da solução nutritiva.
\end{abstract}




\section{INTRODUCTION}

Problems of water and soil salinity are an obstacle for agriculture, especially in the Northeast region of Brazil, due to the edaphoclimatic characteristics of this region. The generation of technologies and studies that allow the use of brackish water in food production becomes important for the agricultural scene. Hydroponics can be consistent with the production in small areas, besides being compatible with family farming, which prevails in this region (Soares, 2007; Paulus et al., 2012).

The Nutrient Film Technique (NFT) stands out as the most viable for the use in commercial facilities and it is common to adopt recirculation frequency of $0.25 \mathrm{~h}$. On the other hand, the Deep Flow Technique (DFT) allows to adopt different recirculation frequencies, because plant roots are maintained in continuous contact with the depth of nutrient solution (NS).

Plants have various mechanisms of tolerance to salinity to protect their vital organs, such as exclusion and/or compartmentalization of ions (Severiano et al., 2014). In lettuce, salinity affects various physiological and biochemical processes along its cycle (Paulus et al., 2010).

The knowledge on the biochemical mechanisms of lettuce plants under saline conditions and in different cultivation techniques is essential to maintain a competitive production in the market using brackish water. However, there are not many studies evaluating biochemical characteristics of lettuce in different hydroponic systems with different recirculation frequencies and with variable water quality, in the same experiment. Thus, this study aimed to evaluate production and accumulation of inorganic solutes in iceberg lettuce (cv. Tainá) cultivated in NFT and DFT systems with brackish water, using different recirculation frequencies of the nutrient solution in the DFT system.

\section{Material ANd Methods}

The experiment was carried out from February 25 to March 25,2015 , in a protected environment, in the municipality of Cruz das Almas, BA, Brazil (12 40’ 19” S, 39 6’ 23” W).

A.

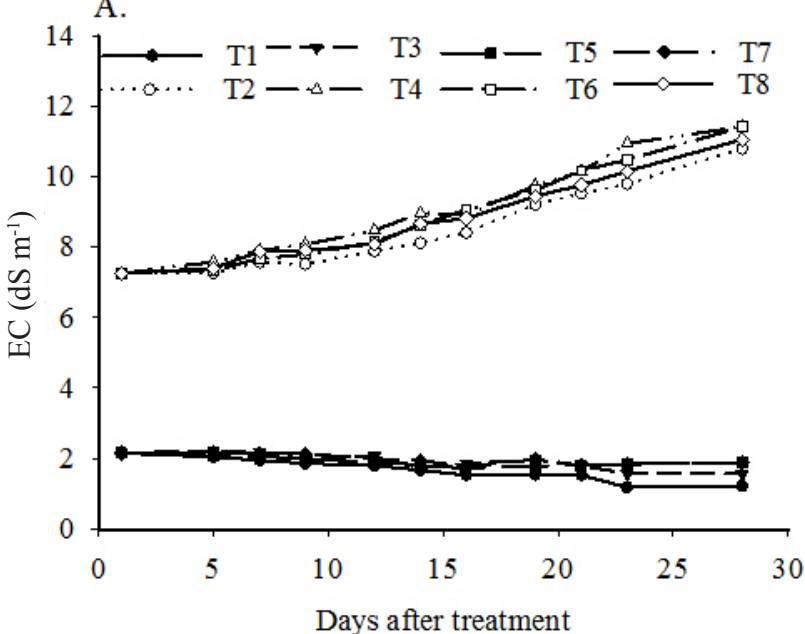

According to Almeida (1999), the local climate is humid hot tropical, Aw and Am according to Köppen's classification, with annual means of rainfall, temperature and relative humidity of $1,224 \mathrm{~mm}, 24.5{ }^{\circ} \mathrm{C}$ and $80 \%$, respectively. During the experimental period, the following temperatures were recorded inside the greenhouse: maximum of $37.9^{\circ} \mathrm{C}$; minimum of 21.8 ${ }^{\circ} \mathrm{C}$ and mean of $26.8^{\circ} \mathrm{C}$, with relative air humidity of $74 \%$.

The experiment consisted in the evaluation of two hydroponic systems: NFT and adapted DFT. For both hydroponic systems, the experimental units were installed as proposed by Soares et al. (2009). The structure was composed of 32 hydroponic profiles, eight with NFT system with $3 \%$ declivity, and 24 with DFT (null declivity). Each plot consisted of a plastic container with capacity for $50 \mathrm{~L}$ and an electric pump for impelling the solution to the hydroponic system. The NS used was based on the recommendation of Furlani (1998) for leafy vegetables. Seeds of iceberg lettuce (cv. Tainá) were sown in phenolic foam. After 15 days from germination, plants were placed in plastic cups with three cuts at the bottom and transferred to cultivation gullies with the respective treatments in the NS.

The electrical conductivity (EC) of the water used to prepare the NS was $0.3 \mathrm{dS} \mathrm{m}^{-1}$ (fresh water). The NS recirculation frequencies were every $0.25 \mathrm{~h}$ in the NFT system and every 0.25 , 2 and $4 \mathrm{~h}$ in the DFT system. Therefore, eight treatmens were performed: T1 $\left(\mathrm{NFT}_{0.25 \mathrm{~h}}, \mathrm{EC}_{0.3}\right) ; \mathrm{T} 2\left(\mathrm{NFT}_{0.25 \mathrm{~h}}, \mathrm{EC}_{5.3}\right) ; \mathrm{T} 3\left(\mathrm{DFT}_{0.25 \mathrm{~h}}\right.$, $\left.\mathrm{EC}_{0.3}\right) ; \mathrm{T} 4\left(\mathrm{DFT}_{0.25 \mathrm{~h}}, \mathrm{EC}_{5.3}\right) ; \mathrm{T} 5\left(\mathrm{DFT}_{2 \mathrm{~h}}, \mathrm{EC}_{0.3}\right) ; \mathrm{T} 6\left(\mathrm{DFT}_{2 \mathrm{~h}}, \mathrm{EC}_{5.3}\right)$; T7 $\left(\mathrm{DFT}_{4 \mathrm{~h}}, \mathrm{EC}_{0.3}\right)$ and T8 $\left(\mathrm{DFT}_{4 \mathrm{~h}}, \mathrm{EC}_{5.3}\right)$ were tested. For any frequency, the time of NS recirculation was $0.25 \mathrm{~h}$.

The synthetic brackish water, used to prepare the NS, was prepared through the addition of $50 \mathrm{mmol} \mathrm{L}^{-1}$ of $\mathrm{NaCl}$ in the NS. The NS level in the containers was daily monitored and water was replenished always when necessary, to maintain a constant NS level. The replenishment of nutrients in the NS was performed always when the EC became 25\% lower than the initial value. The $\mathrm{pH}$ and $\mathrm{EC}$ in the NS were regularly monitored during the crop cycle (Figure 1). In the brackish water treatments, the EC increased every time (Figure 1A) and the evapotranspired water depth was replenished with brackish

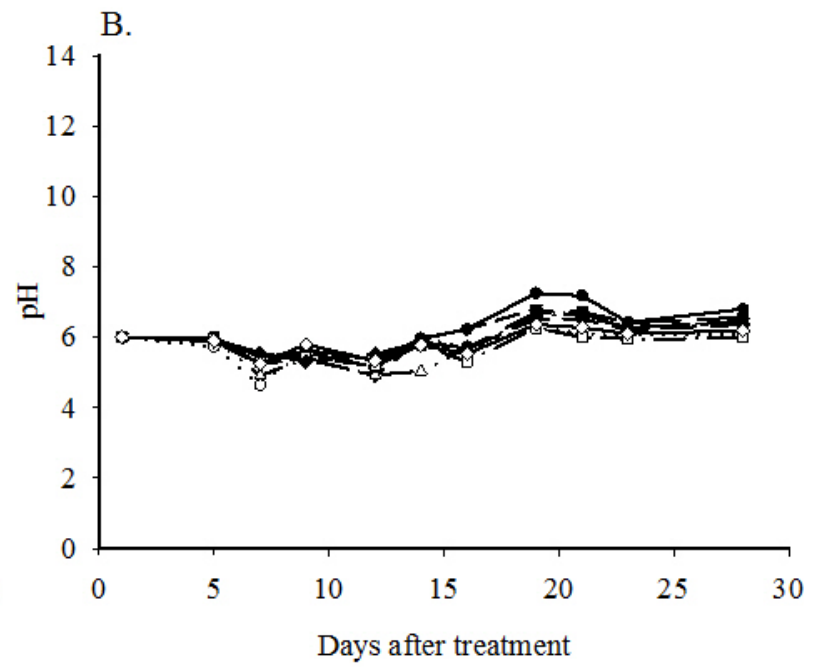

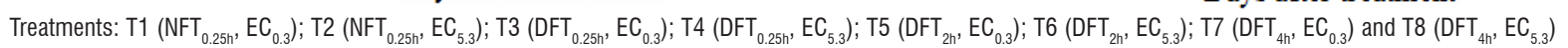

Figure 1. Values of electrical conductivity $(\mathrm{A})$ and $\mathrm{pH}(\mathrm{B})$ in the nutrient solution along the experimental period under different treatments 
water, which did not occur when fresh water was used. There were fluctuations of $\mathrm{pH}$ in the NS during the experimental period, especially in the NS prepared with brackish water (Figure 1B). The correction of $\mathrm{pH}$ was performed always when necessary through the addition of potassium hydroxide or phosphoric acid, to maintain the NS with $\mathrm{pH}$ between 5.5 and 6.5 .

The following variables were evaluated in the iceberg lettuce, cv. Tainá: shoot dry matter production, leaf contents of $\mathrm{Na}^{+}, \mathrm{K}^{+}, \mathrm{Cl}^{-}$and $\mathrm{NO}_{3}^{-}$, and the correlation between shoot dry matter and $\mathrm{Na}^{+} / \mathrm{K}^{+}$and $\mathrm{Cl}^{-} / \mathrm{NO}_{3}{ }^{-}$ratios, after 28 days of cultivation.

Plants were separated into leaves and stems and, after drying at $65{ }^{\circ} \mathrm{C}$, weighed for the determination of shoot dry matter (SDM). The leaves were then ground for the determination of the contents of inorganic solutes: $\mathrm{Na}^{+}, \mathrm{K}^{+}, \mathrm{Cl}^{-}$and $\mathrm{NO}_{3}^{-}$. The extracts were prepared as described by Cataldo et al. (1975), with slight modifications. A portion of $100 \mathrm{mg}$ of the ground leaves and $10 \mathrm{~mL}$ of deionized water were mixed in test tube, which was maintained at temperature of $180^{\circ} \mathrm{C}$, in water bath for $1 \mathrm{~h}$ and with agitation every $15 \mathrm{~min}$. In the extract, the contents of $\mathrm{Na}^{+}$and $\mathrm{K}^{+}$were determined through flame photometry (Sarruge \& Haag, 1974), $\mathrm{Cl}^{-}$contents through spectrophotometry (Gaines et al., 1984) and $\mathrm{NO}_{3}^{-}$contents through the colorimetric method, as described by Cataldo et al. (1975).

The data were subjected to analysis of variance by F test and the variables with significant effects subjected to the ScottKnott means grouping test at 0.05 significance level using the software Sisvar (Ferreira, 2008).

\section{Results AND Discussion}

The salt stress decreased shoot dry matter production of plants regardless of the hydroponic system and NS recirculation frequency (Figure 2), the reductions were more pronounced in the NFT system (45\%) compared to the DFT system (10, 38

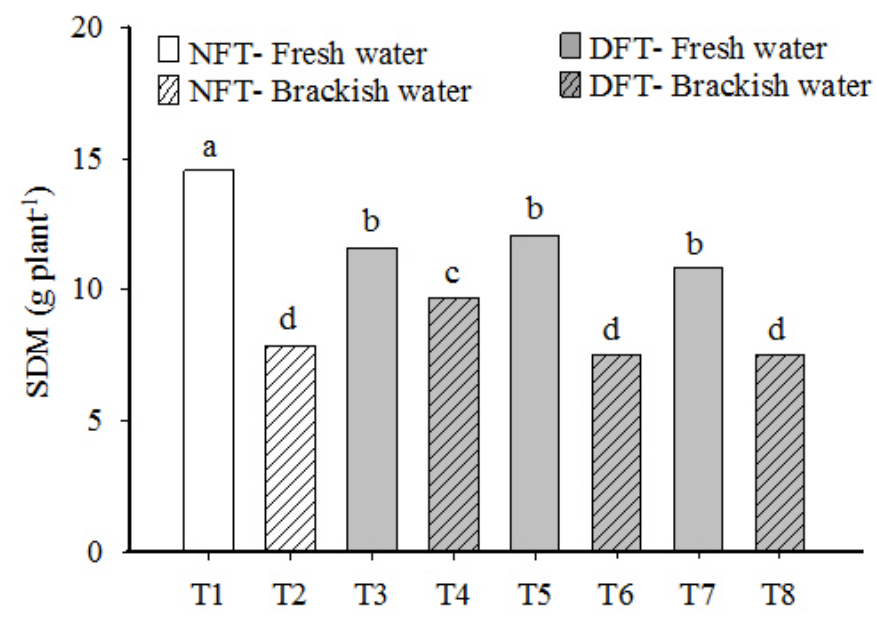

Means followed by the same latter do not differ by Scott-Knott test at 0.05 significance level Figure 2. Shoot dry matter of iceberg lettuce (cv. Tainá) cultivated in NFT and DFT hydroponic systems, at frequencies of $0.25,2$ and $4 \mathrm{~h}$, using nutrient solution prepared with fresh water (T1, T3, T5 and T7) or brackish water (T2, T4, T6 and T8) and $30 \%$ for the frequencies of $0.25,2$ and $4 \mathrm{~h}$, respectively). Comparing the treatments that used fresh water in the NS preparation, it was observed that SDM production in the NFT (T1) was $21.6 \%$ higher than that obtained in DFT systems (T3, T5 and T7). However, among the treatments that used brackish water, the SDM in the DFT system, with recirculation every $0.25 \mathrm{~h}$ (T4), was $21.5 \%$ higher than that obtained in the other salt treatments (T2, T6 and T8).

In the NFT system, lettuce roots remained for some time (interval between two consecutive recirculations) without NS, which increases the probability of plants experiencing water deficit, especially in the hottest periods of the day. In the present study, saline and water stresses were probably responsible for the reduction in lettuce SDM in the NFT system with brackish water. On the other hand, in DFT system, the risk of root drying is less, because of the maintenance of a NS depth in the profiles.

For the DFT system the reduction of the frequency of recirculation of the nutrient solution impaired the dry matter production of lettuce 'Tainá' when using brackish water. No effect of recirculation frequency was observed when fresh water was used in this system.

The data of the present study indicate that the choice of the hydroponic system and NS recirculation interval in lettuce cultivation depends on the quality of the water used. Thus, while the NFT system, at $0.25 \mathrm{~h}$, proved to be the most adequate for cultivation using NS prepared with fresh water, the DFT at $0.25 \mathrm{~h}$ was the most indicated to be used for cultivation using NS prepared with brackish water. It is noteworthy that using fresh water it was possible to produce lettuce in DFT system with the lowest recirculation frequency ( $4 \mathrm{~h}$ ), among the evaluated ones.

Salinity increased the contents of $\mathrm{Na}^{+}$and $\mathrm{Cl}^{-}$and reduced that of $\mathrm{K}^{+}$and $\mathrm{NO}_{3}^{-}$in lettuce leaves, regardless of the production system and NS recirculation frequency (Figure 3A, 3B).

In the NFT system, the contents of $\mathrm{Na}^{+}$and $\mathrm{Cl}^{-}$in lettuce leaves were, on average, 11 and 3 times higher than those obtained in plants cultivated with NS prepared with fresh water, respectively. In the DFT system, NS salinity increased the contents of $\mathrm{Na}^{+}$and $\mathrm{Cl}^{-}$in lettuce leaves by 16 and 5 times, on average, respectively. Various studies have demonstrated increase in the contents of these ions in plants subjected to addition of $\mathrm{NaCl}$ in the NS (Ekinci et al., 2012; Paulus et al., 2012; Sacramento et al., 2014; Bartha et al., 2015). In lettuce, according to Bartha et al. (2015) $\mathrm{Na}^{+}$accumulation in the leaves leads to better osmotic adjustment of the plants to saline stress.

The contents of $\mathrm{Na}^{+}$and $\mathrm{Cl}^{-}$were not influenced by the NS recirculation frequency in the DFT system. However, by comparing the leaf $\mathrm{Na}^{+}$contents in the brackish water treatments, it can be observed that the value in the NFT system (T2) was $18 \%$ higher than mean value found in the DFT system (T4, T6 and T8).

The contents of $\mathrm{Cl}^{-}$in leaves of brackish water treatments did not differ between the hydroponic cultivation systems. In the NFT, the higher contents of $\mathrm{Na}^{+}$, as mentioned earlier, may be related to the absence of NS in the roots, during the recirculation intervals. This absence may have caused a temporary water deficit in the plants, with reflexes in transpiration and ion uptake (Santos et al., 2011). 


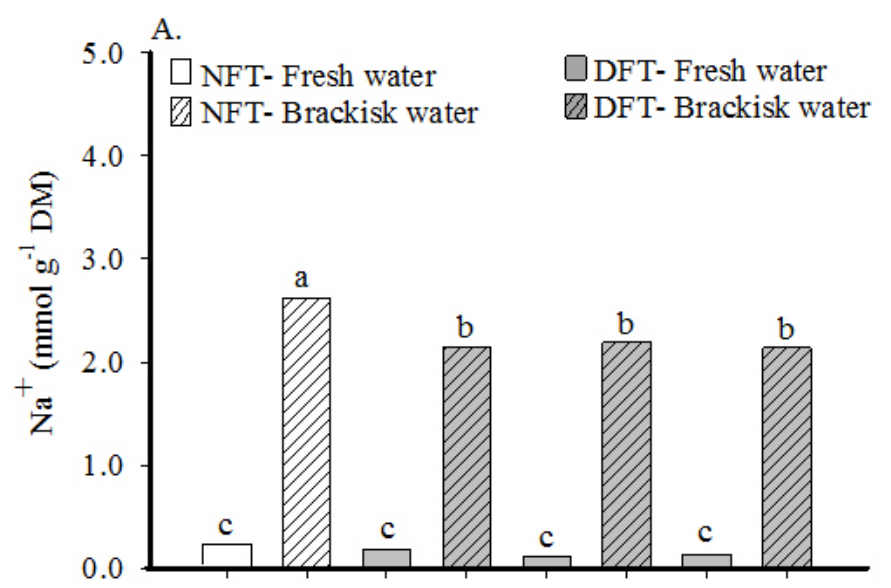

C.
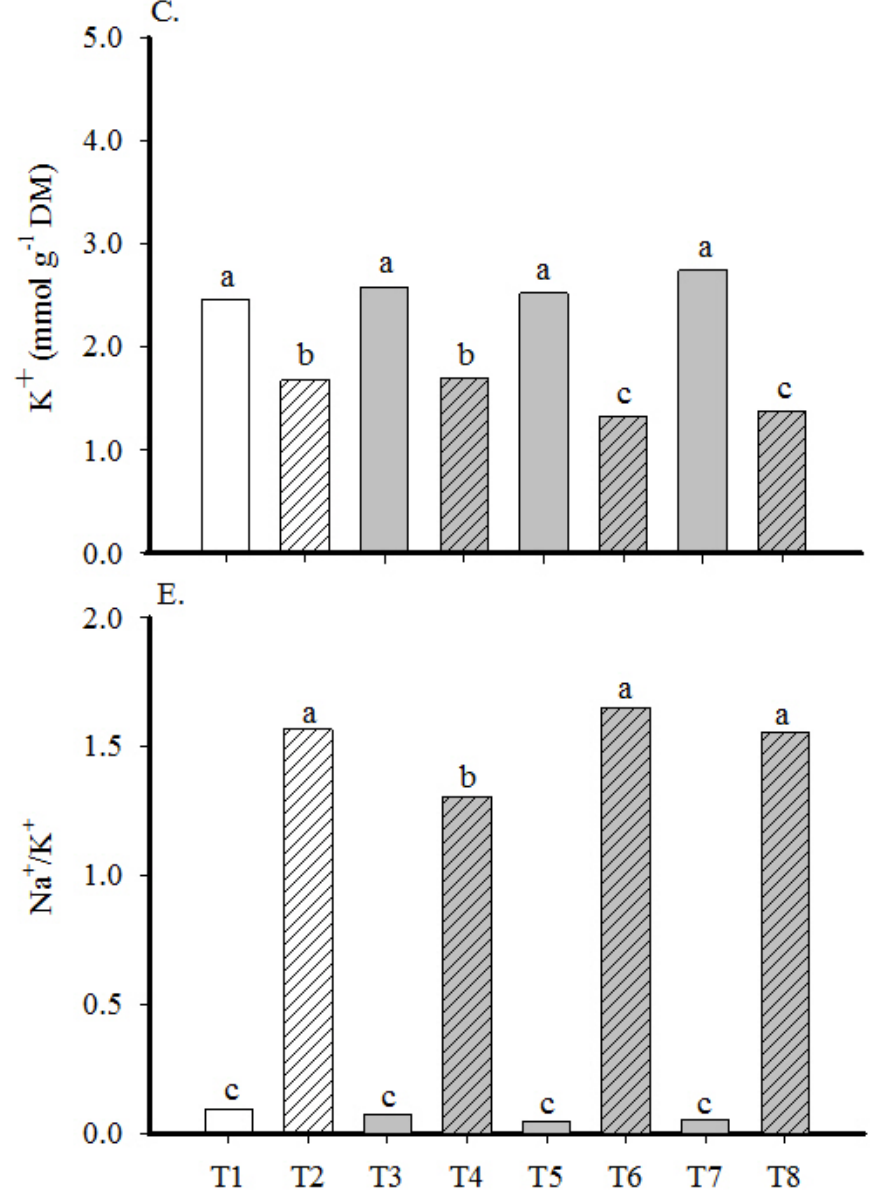

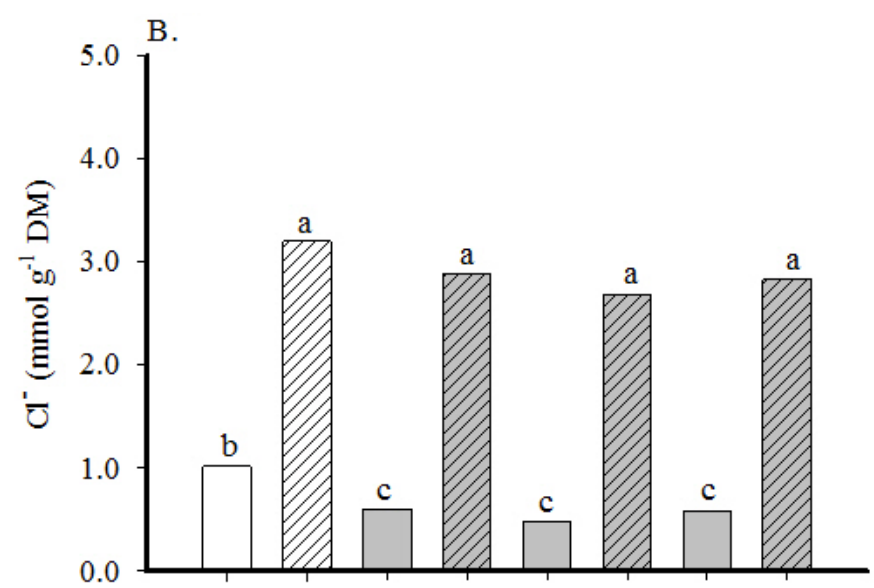

D.
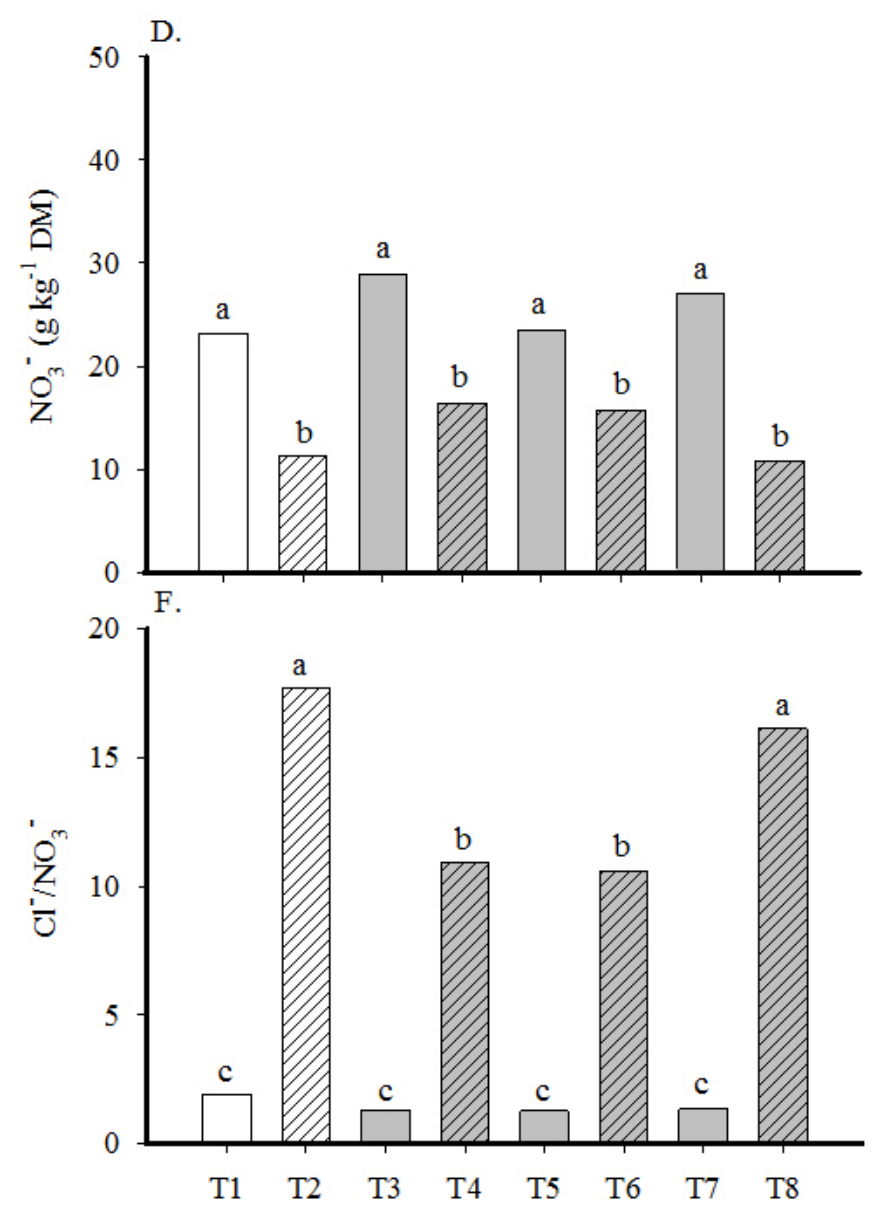

Means followed by the same letters do not differ by Scott-Knott test at 0.05 significance level

Figure 3. Contents of $\mathrm{Na}^{+}(\mathrm{A}), \mathrm{Cl}^{-}(\mathrm{B}), \mathrm{K}^{+}(\mathrm{C}), \mathrm{NO}_{3}^{-}(\mathrm{D})$ and ratios of $\mathrm{Na}^{+} / \mathrm{K}^{+}(\mathrm{E})$ and $\mathrm{Cl}^{-} / \mathrm{NO}_{3}^{-}(\mathrm{F})$ in leaves of iceberg lettuce (cv. Tainá) cultivated in NFT and DFT hydroponic systems with recirculation frequencies of $0.25,2$ and $4 \mathrm{~h}$ of the nutrient solution prepared with fresh water (T1, T3, T5 and T7) or brackish water (T2, T4, T6 and T8)

The contents of $\mathrm{K}^{+}$in the plants of treatments with fresh water (T1, T3, T5 and T7) did not differ, regardless of the hydroponic system and recirculation frequency (Figure 3C). However, among the salt treatments, it can be observed that the $\mathrm{K}^{+}$content was lower in those with recirculation intervals of 2 and $4 \mathrm{~h}$ (T6 and T8, respectively) than in the recirculation interval of $0.25 \mathrm{~h}$ (T2 and T4).

Under salt conditions, $\mathrm{K}^{+}$uptake can be affected by $\mathrm{Na}^{+}$, due to the physicochemical similarities between these two ions (Sperling et al., 2014). This antagonism frequently results in reduction of $\mathrm{K}^{+}$contents, leading to disorders in the metabolic activity of the plants (Mekawy et al., 2015).
The contents of $\mathrm{NO}_{3}{ }^{-}$under salinity decreased, on average, by $47 \%$ when compared with the fresh water treatments in both systems, however, no significant differences $(p>0.05)$ were observed in the brackish water treatments (Figure 3D). Therefore, the variation in nitrate contents among treatments was more related to the effect of salinity than to the hydroponic systems and recirculation frequencies.

Reductions in $\mathrm{NO}_{3}{ }^{-}$contents in lettuce cultivars under saline stress were also reported by Pérez-López et al. (2015). The concentration of nitrate in lettuce varies according to varieties and cultivation conditions, exhibiting values between 0.94 and $3.42 \mathrm{~g} \mathrm{~kg}^{-1}$ of fresh matter (FM) (Paulus et 
al., 2012). Other factors, such as light intensity, temperature, relative air humidity growing season can also affect the nitrate accumulation in lettuce leaves (Santos et al., 2010).

According to Sandri et al. (2006), values ranging from 1.09 to $1.38 \mathrm{~g} \mathrm{~kg}^{-1}$ (on fresh weight basis) are considered as adequate for lettuce plants, cultivated in soil. Considering that, in the present study, the mean water content in lettuce leaves was 96\% (data not shown), the leaf $\mathrm{NO}_{3}{ }^{-}$content in the FM will be equivalent to 0.93 to $1.15 \mathrm{~g} \mathrm{~kg}^{-1}$ in control plants and 0.43 to $0.66 \mathrm{~g} \mathrm{~kg}^{-1}$ in stressed ones. Thus, the growth reduction in treatments in which the NS was prepared using brackish water may, at least partially, be related to a salt-induced $\mathrm{N}$ deficiency.

From the point of view of human health the consumption of vegetables rich in nitrate may cause damages and, in Brazil, the monitoring is made based on the European indices (Luz et al., 2008). For lettuce cultivated in protected environment, the limit is $4.5 \mathrm{~g} \mathrm{~kg}^{-1}$ of FM in the winter and $3.5 \mathrm{~g} \mathrm{~kg}^{-1}$ of FM in the summer (EC, 2006). Therefore, the $\mathrm{NO}_{3}{ }^{-}$content verified in this work was much lower than the maximum limit established for consumption by EC.

The increase in $\mathrm{Na}^{+}$contents associated with the reduction in $\mathrm{K}^{+}$contents resulted in increase of $\mathrm{Na}^{+} / \mathrm{K}^{+}$ratios in stressed plants, which varied from 1.30 to 1.65 (Figure $3 \mathrm{E}$ ); however, in the DFT system at $0.25 \mathrm{~h}$, the $\mathrm{Na}^{+} / \mathrm{K}^{+}$ratio was about $18 \%$ lower than that observed in the other saline treatments. According to Greenway \& Munns (1980), $\mathrm{Na}^{+} / \mathrm{K}^{+}$ratios equal to or lower than 1.0 are necessary for the occurrence of optimal metabolic efficiency in glycophytes. In the present study, the values of this ratio in stressed plants were above this limit, suggesting that their metabolism was affected by salinity, which can partially explain the reduction in plant growth.

Salinity also increased the $\mathrm{Cl}^{-} / \mathrm{NO}_{3}{ }^{-}$ratios. The highest values were observed in the NFT system (T2) and DFT system with $4 \mathrm{~h}$ (T8) (Figure 3F). Salinity can decrease the $\mathrm{NO}_{3}{ }_{3}^{-}$uptake, this occurs due to the direct competition between $\mathrm{Cl}^{-}$and $\mathrm{NO}_{3}$ ions by the same transporter, which may cause $\mathrm{N}$ deficiency in the plants (Fageria et al., 2011; Feijão et al., 2013).

The $\mathrm{Na}^{+} / \mathrm{K}^{+}$ratio in the leaves of stressed plants showed a negative correlation coefficient $(\mathrm{r}=-0.97)$, highly significant $(\mathrm{p}<$ 0.01 ) with SDM. In contrast, the correlation coefficient between the $\mathrm{Cl}^{-} / \mathrm{NO}_{3}{ }^{-}$ratio and the SDM $(\mathrm{r}=-0.36)$ was not significant ( $p>0.05)$. These data indicate that the dry matter production of lettuce was more affected by the imbalance between $\mathrm{Na}^{+}$and $\mathrm{K}^{+}$ than by the imbalance between $\mathrm{Cl}^{-}$and $\mathrm{NO}_{3}$.

The characteristics of the NFT and DFT hydroponic systems influenced $(\mathrm{p}<0.05)$ the $\mathrm{Na}^{+}$content, whereas in the DFT system the recirculation frequency influenced $(\mathrm{p}<0.05)$ the $\mathrm{K}^{+}$content and the ratios $\mathrm{Na}^{+} / \mathrm{K}^{+}$and $\mathrm{Cl}^{-} / \mathrm{NO}_{3}$.

\section{Conclusions}

1. The NFT system, with recirculation interval of 0.25 $\mathrm{h}$ is the most indicated for production of lettuce cv. Tainá with nutrient solution prepared with fresh water, while the DFT system with the same interval recirculation is the most indicated for nutrient solution prepared with brackish water.

2. The imbalance in the $\mathrm{Na}^{+} / \mathrm{K}^{+}$ratio and the lower $\mathrm{NO}_{3}$ contents in leaves may, at least in part, explain the growth reduction of lettuce under salt stress.

\section{ACKNOWLEDgMents}

To the Coordination for the Improvement of Higher Education Personnel (CAPES), for granting the scholarship to the first author; to the Bahia Research Support Foundation (FAPESB), the National Institute of Science and Technology in Salinity (INCTSal) and to the National Council for Scientific and Technological Development $(\mathrm{CNPq})$ for the financial support for the hydroponic infrastructure.

\section{Literature Cited}

Almeida, O. A. Informações meteorológicas do CNP: Mandioca e Fruticultura Tropical. Cruz das Almas: Embrapa CNPMF. 1999. 35p. Documentos, 34.

Bartha, C.; Fodorpataki, L. Martinez-Ballesta, M. C.; Popescu, O.; Carvajal, M. Sodium accumulation contributes to salt stress tolerance in lettuce cultivars. Journal of Applied Botany and Food Quality, v.88, p.42-48, 2015.

Cataldo, D. A; Haroon, M.; Schrader, L. E.; Youngs, V. L. Rapid colorimetric determination of nitrate in plant tissue by nitration of salicylic acid. Soil Science and Plant Analysis, v.6, p.71-80, 1975. https://doi.org/10.1080/00103627509366547

EC - Comission Regulation. ACT No. 1881/2006 of 19 December 2006. <http://eur-lex.europa.eu/legal-content/EN/TXT/ $\mathrm{PDF} /$ ?uri=CELEX:32006R1881\&from=EN $>.6$ Jan. 2016.

Ekinci, M.; Yildirim, E.; Dursun, A. Mitigation of salt stress in lettuce (Lactuca sativa L. var Crispa) by seed and foliar24-epibrassinolide treatments. American Society for Horticultural Science, v.47, p.631-636, 2012.

Fageria, N. K.; Gheyi, H. R.; Moreira, A. Nutrient bioavailability in salt affected soils. Journal of Plant Nutrition, v.34, p.945-962, 2011. https://doi.org/10.1080/01904167.2011.555578

Feijão, A. R.; Marques E. C.; Silva, J. C. B.; Lacerda, C. F. de; Prisco, J. T.; Gomes Filho, E. Nitrato modula os teores de cloreto e compostos nitrogenados em plantas de milho submetidas à salinidade. Bragantia, v.72, p.10-19, 2013. https://doi.org/10.1590/ S0006-87052013005000021

Ferreira, D. F. Programa SISVAR: Sistema de análise de variância. Versão 4.6 (Build 6.0). Lavras: DEX/UFLA. 2008.

Furlani, P. R. Instrução para o cultivo de hortaliça de folha pela técnica de hidroponia-NFT. Campinas: Instituto Agronômico, 1998. 30p. Boletim Técnico, 168

Gaines, T. P.; Parker, M. B.; Gascho, G. J. Automated determination of chlorides in soil and plant tissue by sodium nitrate extraction. Agronomy Journal, v.76, p.371-374, 1984. https://doi.org/10.2134/ agronj1984.00021962007600030005x

Greenway, H.; Munns, R. Mechanism of salt tolerance in nonhalophytes. Annual. Reviews. Plant Physiology, v.31, p.149-190, 1980. https:// doi.org/10.1146/annurev.pp.31.060180.001053

Luz, G. L. da; Medeiros, S. L. P.; Manfron, P. A.; Amaral, A. D. do; Müller, L.; Torres, M. G.; Mentges, L. A questão do nitrato em alface hidropônica e a saúde humana. Ciência Rural, v.38, p.23882394, 2008. https://doi.org/10.1590/S0103-84782008000800049

Mekawy, A. M. M.; Assaha, D. V. M.; Yahagi, H.; Tada, Y.; Ueda, A.; Saneoka, H. Growth, physiological adaptation, and gene expression analysis of two Egyptian rice cultivars under salt stress. Plant Physiology and Biochemistry, v.87, p.17-25, 2015. https:// doi.org/10.1016/j.plaphy.2014.12.007 
Paulus, D.; Dourado Neto, D.; Frizzone, J. A.; Soares, T. M. Produção e indicadores fisiológicos de alface sob hidroponia com água salina. Horticultura Brasileira, v.28, p.29-35, 2010. https://doi. org/10.1590/S0102-05362010000100006

Paulus, D.; Dourado Neto, D.; Paulus, E. Análise sensorial, teores de nitrato e de nutrientes de alface cultivada em hidroponia sob águas salinas. Horticultura Brasileira, v.30, p.18-25, 2012.

Pérez-López, U.; Miranda-Apodaca, J.; Lacuesta, M.; Mena-Petite, A.; Munoz-Rueda, A. Growth and nutritional quality improvement in two differently pigmented lettuce cultivars grown under elevated $\mathrm{CO}_{2}$ and/or salinity. Scientia Horticulturae, v.195, p.55-66, 2015. https://doi.org/10.1016/j.scienta.2015.08.034

Sacramento, B. L. do; Silva, L. L.; Cruz, T. S.; Abreu, C. B. de; Azevedo Neto, A. D. de. A baixa salinidade não afeta o crescimento e a nutrição mineral de plantas de aguapé. Enciclopédia Biosfera, v.10, p.1969, 2014.

Sandri, D.; Matsura, E. E.; Testezlaf, R. Teores de nutrientes na alface irrigada com água residuária aplicada por sistemas de irrigação. Engenharia Agrícola, v.26, p.45-47, 2006. https://doi.org/10.1590/ S0100-69162006000100006

Santos, A. N. dos; Silva, Ê. F. de F. e; Soares, T. M.; Dantas, R. M. L.; Silva, M. M. da. Produção de alface em NFT e Floating aproveitando água salobra e o rejeito da dessalinização. Revista Ciência Agronômica, v.42, p.319-326, 2011. https://doi. org/10.1590/S1806-66902011000200009
Santos, C. M. G.; Braga, C. de L.; Vieira, M. R. da S.; Cerqueira, R. C.; Brauer, R. L.; Lima, G. P. P. Qualidade da alface comercializada no município de Botucatu - SP. Revista Iberoamericana de Tecnología Postcosecha, v.11, p.67-74, 2010.

Sarruge, J. R.; Haag, H. P. Análise química em plantas. Piracicaba: ESALQ, 1974. 56p.

Severiano, L. S.; Lima, R. de L. S. de; Castilho, N.; Lucena, A. M. A.; Auld, D. L.; Udeigwe, T. K. Calcium and magnesium do not alleviate the toxic effect of sodium on the emergence and initial growth of castor, cotton, and safflower. Industrial Crops and Products, v.57, p.90-97, 2014. https://doi.org/10.1016/j. indcrop.2014.03.015

Soares, T. M. Utilização de águas salobras no cultivo da alface em sistema hidropônico NFT como alternativa agrícola condizente ao semi-árido brasileiro. Piracicaba: ESALQ, 2007. 267p. Tese Doutorado

Soares, T. M.; Duarte, S. N.; Silva, Ê. F. de F. e; Mélo, R. F.; Jorge, C. de A.; Oliveira, A. S. de. Experimental structure for evaluation of brackish water use in lettuce hydroponic production. Irriga, v.14, p.102-114, 2009.

Sperling, O.; Lazarovitch, N.; Schwartz, A.; Shapira, O. Effects of high salinity irrigation on growth, gas-exchange, and photoprotection in date palms (Phoenix dactylifera L., cv. Medjool). Environmental and Experimental Botany, v.99, p.100-109, 2014. https://doi. org/10.1016/j.envexpbot.2013.10.014 